\title{
Contribution of Non Timber Forest Products to Rural Household Income in Eastern Cape Province, South Africa
}

\author{
Onomu Achoja Roland \\ Department of Agricultural Economics and Extension, University of Fort Hare, Alice, \\ Email:201411986@ufh.ac.za \\ Akeem Adewale Oyelana \\ Department of Business Management, University of Fort Hare, Alice, \\ P.B. X1314, Eastern Cape, 5700, South Africa \\ 201100592@ufh.ac.za
}

\section{Doi:10.5901/mjss.2014.v5n23p749}

\begin{abstract}
The operations of Non Timber Forest Products (NTFPs) to rural household income in Eastern Cape Province of South Africa are not well understood and have rarely been addressed worldwide. The aim of this study was therefore to establish a base level of understanding of the operational core values of (NTFPs) in a develop country. Data was collected through structured self-administered questionnaires and interview. A multi stage sampling procedure was used to select the respondents. Data analysis included using descriptive statistics involving the use of percentage and tables as well as regression analysis as the statistical tools. Findings from previous literature revealed that there are constraints faced in the operations of (NTFPs). The field survey confirmed some of the operational challenges to include Lack of marketing, distance from forest as well as over exploitation. The findings also identified the search for solutions to these challenges by providing an insight for further research regarding the institutional weaknesses and policy issues in this part of the world. The implications of the findings are that unless the limitations named above are resolved, NTFPs in a developing nation will continue to experience poor economic growth, development and display inferior competitiveness. Recommendations to overcome these challenges are suggested.
\end{abstract}

Keywords: Contribution, Non Timber, Forest, Products, Rural, Household, Income, Eastern Cape, Province, South Africa.

\section{Introduction}

Frank (1997) stated that forest products (foods) are often particularly important for poorer groups of rural people. They provide an available and accessible source of a diverse range of foods. Especially important are wild animals and fishes as well as seasonally available fruits, leaves, nuts and mushrooms. He also noted that, in some cases, the availability of forest food may allow farmers to market a greater share of their agricultural produce. This will lead us to define forest where forest products are gotten from. Tukudo et al (1994) defined forestry as skilful management of all natural resources, which occurred on and for greater human benefit. The main goal of forestry is to create and implement a system that allow forest to continue as sustainable continuation of environmental supplied and services (Gale, 2001). Most people rely on fuel wood to meet their energy needs such as cooking and heating. They collect folder for their livestock. They also collect food products such as wild fruit, vegetable, nuts, edible roots, bush meat, edible insects, honey, and food additives like spices, flavouring, and fermentation agent (Abushe, 2005).

Majority of the rural dwellers in most developing countries meet some parts of their construction, storage, agricultural, energy, nutritional and medicinal needs from forest. Access to forest resources helps rural household to diversify their consumption. Large numbers of people generate some of their income from selling forest products. Forest products provide sources of varieties of food that supplement and complement what is obtained from agriculture. The trees help to create a special environment which in turn affects the kind of animals and plants that exist in the forest. The trees conserve heat and act as an excellent sound absorber (Gale, 2001). Lynch and Talbott (1992) stated that up to 500 million people who live in or at the edge of tropical forest depend on the forest for many important products and environmental resources. The forest does not only meet their economic needs for food and shelter but also form an integral part of their culture and spiritual tradition (World Commission on Forest and Sustainable Development, WCFSD, 1997). The poorest household depends on plant and animal products of the forest. The forest provides us with a wide 
range of industrial wood products that we used for poles, pulp and paper making. Indication has shown that more and more people will continue to use fuel wood as it is preferred to gas, paraffin, electricity, coal and solar energy, as these and their cooking appliances are costly and outside the economic reach of the ordinary third world citizen (Tukudo et al., 1994).

Agbogidi and Ofuoko (2006) identified one of the sources of poverty as over exploitation of natural resources, which has resulted in the destabilization and depletion of biodiversity. This has the consequence of causing climate change. Hence there is need to reduce the rate at which forest products are being exploited without replacement. Forest tree is one of the forest products that is constantly exploited. Therefore, one can say that there is a sharp rate of deforestation. Hence this study will evaluate the contribution of non timber forest products on the income of household using Knysna-Amatole Montane Forests Ecoregion of the tropical and subtropical moist broadleaf forests Biome in South Africa. It covers an Afromontane area of 3,100 square Kilometres $(1,200 \mathrm{sq} \mathrm{ml})$ in the Eastern Cape Province of South Africa.

\section{Literature Review}

\subsection{Economic Important of Forest Resource}

Food and Agriculture Organisation, FAO (1990), defined forest as land with trees crown covered or equivalent stoking level of more than 0.5 hectare. Anon (1996) reported that forest is the home of $70 \%$ of the world's plants and animals. Forest influences local and probably global climate. They moderate the range of air temperature and maintained atmospheric humidity. Forests are often important sources of food stuff for man. It also provides employment opportunities to sustain the citizenry of a nation generate income and thus improved their standard of living.

The imperatives and economic potential of the tropical forest resources varies from area to area. Forest products have the ability to make a major contribution to development by meeting basic needs in energy and other areas. Forest products contribute to food security; sustain environmental stability and provision of income to rural dwellers. Forest products stimulate rural economic development and contributed to poverty reduction (FAO, 2009). Other importance of forest resources includes regulation of soil and water flow as well as shading the soil from direct sun light intensity. It acts as windbreak protector. Forest also contributed to livestock production through silvipastoral system, particularly the creation of fodder resources or bank in form of fodder tree or scrubs to cushion the calamities of drought. It served a fundamental role in the maintenance of soil water for food production. Forest provides fuel wood and other forest products such as fruits leave and wild life to rural household. It contributes to rural employment through cottage industries base on materials derived from wild plants and animals and the development of wild base tourism. It lowers greenhouse gas emission.

Etukudo (2000) opines that in the rural areas where the popular food eaten is mainly Carbon hydrates, indigenous fruits trees fulfil a very useful role in improving food quality by providing protein, minerals, vitamins and fats. Etukudo (2000) noted that honey is used as a stimulant, tonic and as a component of many medicines. It is good for the heart, liver and in treating burns. It is mixed with herbs to treat whooping cough, asthma, influenza, jaundice and pile. He also stated that fodder trees and shrubs have an important advantage over fodder grasses and herbaceous legumes. During the severe dry months of the year, the grasses and herbaceous legume dry out. The trees and shrubs continue to provide fodder since they are deep rooted and they tap deep underground moisture reserves not easily reached by roots of grasses and legumes, therefore animals can feed all year round. All of these and some other products are gotten from the forest.

\subsection{Environmental Impact of Over Exploitation of Non Timber Forest Products}

The various causes of deforestation are urbanization, Industrialization, new-settlement, grazing and ranching, construction of large dam, human population growth, type of farm practices, bush burning, and logging, fuel wood exploitation and fossil burning. Among these factors, fuel-wood exploitation and fossil burning have the greatest ability to exacerbate and contribute to deforestation and climate change than other causes. Deforestation is the removal of forest or stand of trees, there after the land is converted for non forest use. Larman and Rodger (1992) defined deforestation as the permanent loss of forest for other land uses, such as agriculture, new settlement and dam reservoir. In some cases, deforestation can be beneficial, given the right or social needs and environment conditions. Nevertheless, if not checked, it has the ability to impinge on the environment in many ways such as:

- reduction of soil fertility and hence agricultural output, 
- environmental pollution, health and disease hazard, climate change, and desertification,

- losses of forest resources.

Reduction of soil fertility and agricultural output; Indiscriminate exploitation of forest resources has a negative impact on agriculture, it leads to flooding. Hence, there is degradation of the soil, Soil degradation is the reduction in land potential uses (Blaikie and Harold, 1987). International Institute of Tropical Agriculture, IITA (1986) reported that trees and scrubs have been used for centuries in forming system to accelerate the restoration of soil fertility. But if these trees and scrubs are not there, what will happen to the soil and agricultural output?. There will be sharp decline in output. Lietz et al. (1999) stated that the yield of corn and sorghum would decline as much as 60 percent over decade in the absence of soil conservation measure.

\subsection{Environmental Pollution of Over Exploitation of (NTFPs)}

When the trees that should absorb carbon dioxide, $\left(\mathrm{CO}_{2}\right)$ are removed, then the concentration of $\mathrm{CO}_{2}$ in the atmosphere becomes too much. More also burning of fuel energy increase the amount of smoke in the environment consequently resulting in inhalation of Shocking air. The earth's atmosphere is a mixture of chemical gases, rather than a chemical compound. The gases are about 50 percent constant in proportion of dry air. These gases are nitrogen, oxygen, argon and carbon dioxide, making up $99.8 \%$ of the air by volume (Barry and chorley, 1982). In addition, there are significant quantities of qerosol, in the atmosphere. These include suspended particle of sea salt, dust (particularly, silicate), organic matter and smoke. If all of these gases are left in the atmosphere as a result of indiscriminate exploitation of non timber forest products such as fuel wood and air pollution will be resulted.

\subsection{Health and disease Implication of Non Timber Forest Products Exploitation}

Fuel wood exploitation is one of the (NTFP) that is constantly exploited. It exposed the soil to direct sum light radiation. It can increase the intensity of heat wave on the earth surface as well as increase space cooling needs. This contributes to incident or change in the ecological indices, leading to increasing incident of disease vectors, communicable disease and epidemics (Nigeria Environmental Study Action, NEST, 2003).

\subsection{Impact of Non Timber Forest Products Extraction on Climate change}

Impact of fuel wood utilization on climate change has been noticed. The major causes of climate change are deforestation and fossil burning. The earth's energy source is principally the sun, generating solar radiation at short wavelength. Only approximately $70 \%$ of the total radiations heat the earth and its atmosphere. However, much of this heat is received second hand by atmosphere via the earth surface as the atmosphere is largely transparent to solar radiation. Specifically, the earth absorbs about $45 \%$ of the incoming energy available at the top of the atmosphere and reradiates it outward as (in-fare) waves. Water vapour, carbon dioxide and Ozone in the atmosphere can absorb much of this re-radiated long wave energy. The rest is lost through atmosphere windows into outer space. However, as water vapour and carbon dioxide absorb in-fared radiation, the process creates a green house effect, which have lately been implicated as a major cause of global climate Soper et al., (1997) reported that, the release of some of this stored carbon into the atmosphere as carbon dioxide has increased in recent time with the burning of large amounts of fossil fuel and with larger scale deforestation. Carbon dioxide is normally present in the lower atmosphere, the troposphere in every small amount, about 300 PPM or $0.03 \%$ by volume. Its importance lies in its contribution to the planetary greenhouse effect consequently leading to climate change.

\subsection{Loss of forest resources}

Another adverse effect of non timber forest products exploitation on the environment is loss of forest resources. FAO (1999) estimated that 1.5 billion of the 2 billion people worldwide who rely on fuel wood for cooking and heating are overcutting forest. The rate at which the forest is exploited has drastically reduced forest resources.

\subsection{Impact of Non Timber forest products Exploitation on rural household}

As earlier stated, agricultural produced and forest products are the main sources of rural household income and food. Foods from forest products are often important as complement to other agricultural produced. Very large numbers of 
household get some of their foodstuff from forest. They also generate income from forest products such as fuel-wood, fruits, gum, snail often when farm product is not enough to provide self sufficiency year round (Andel, 2006). The same way Akaeze, (2010) reported that income from fuel-wood occupied more than $26 \%$ of the total income gotten from forest product by household. A substantial amount of fuel wood is traded commercially through an extensive network of producer. Buyer of non timber forest products are urban and some rural household, commercial enterprise such as restaurants, food vendors and industries. Significant numbers of rural populations are employed into non timber forest products trade (FAO, 1990). The contribution of forest products to rural household should never be under estimated. FAO (1997) stated that industrial wood harvesting alone account for about $2 \%$ of the world's GDP. In a like Manner, Abushe, (2005) reported that fuel-wood exploitation helps to meet household income and shelter needs.

\subsection{Rural household Income}

Rural household income is the total income of all members of rural household. Household income is a measure commonly use by the united state government and private institution that count the income of all members of a rural farm household over the age of 18 in each household. FAO (2008) reported that women practise traditional agro-forestry production system such as selling of wood, fruits, spices, edible worm, honey, snail et cetera are mainly responsible for rural household income.

\section{Methodology}

The study area is Knysna-Amatole Montane Forests Ecoregion of the tropical and subtropical moist broadleaf forests Biome in the Eastern Cape of South Africa Area. A multi stage sampling procedure was used to select respondents. First stage involved random sampling. Second stage involves random selection of 10 respondents from each of the selected areas. Data for the study was collected from primary sources. The data was obtained with the use of structured questionnaire and interview. The questionnaires were administered to literate household. The questionnaire is structure in such a way that it consists of multiple choice questions. The researchers also had a series of interview with some of the rural household members thereby extracting useful information from those rural household members who are deeply involved in using non timber forest products as means of income generation. The information was complemented with secondary data from Department of Forestry. Data in this study was collected based on gender, marital status, age of members of the household and income level of members of household head. Data analysis included using various statistical tools. Descriptive statistics involving the use of percentage and tables as well as regression analysis was used in achieving the objectives of this study.

\section{Results and Discussion}

The table of analysis and discussion are presented under this section.

\subsection{Demographic Characteristic of Respondents.}

This section dealt with the age range, gender, educational background, marital status of household members, who were mostly involved in the extraction of non timber forest products. 
Table 4.1 socioeconomic characteristics of respondents

\begin{tabular}{|c|c|c|}
\hline Variables & Frequency & Percentage \\
\hline \multicolumn{3}{|l|}{ Age (years) } \\
\hline 20 and below & 6 & $8.32 \%$ \\
\hline $21-30$ & 18 & $18.95 \%$ \\
\hline $31-40$ & 27 & $28.42 \%$ \\
\hline $41-50$ & 32 & $33.68 \%$ \\
\hline 51 and above & 12 & $12.63 \%$ \\
\hline Total & 95 & $100 \%$ \\
\hline \multicolumn{3}{|l|}{ Gender } \\
\hline Men & 58 & $61.05 \%$ \\
\hline Women & 37 & $38.95 \%$ \\
\hline Total & 95 & $100 \%$ \\
\hline \multicolumn{3}{|l|}{ Educational Level } \\
\hline Formal Education & 68 & $71.58 \%$ \\
\hline Non-Formal Education & 27 & $28.42 \%$ \\
\hline Total & 95 & $100 \%$ \\
\hline \multicolumn{3}{|l|}{ Marital Status } \\
\hline Single & 10 & $10.53 \%$ \\
\hline Married & 40 & $42.11 \%$ \\
\hline Divorced & 14 & $14.74 \%$ \\
\hline Widow & 20 & $21.05 \%$ \\
\hline Widower & 11 & $11.58 \%$ \\
\hline Total & 95 & $100 \%$ \\
\hline \multicolumn{3}{|l|}{ Occupation } \\
\hline Farming & 42 & $44.21 \%$ \\
\hline Trading & 23 & $24.21 \%$ \\
\hline Civil Servant & 8 & $8.42 \%$ \\
\hline Local Crafting & 5 & $5.26 \%$ \\
\hline Forest Base Activities & 9 & 8.42 \\
\hline Total & 95 & $100 \%$ \\
\hline \multicolumn{3}{|l|}{ Household Size } \\
\hline Below 5 & 36 & $37.89 \%$ \\
\hline $6-10$ & 47 & $49.47 \%$ \\
\hline $11-15$ & 12 & $12.63 \%$ \\
\hline 16 and above & 5 & $5.26 \%$ \\
\hline Total & 95 & $100 \%$ \\
\hline
\end{tabular}

Source: 2014 field data

\subsubsection{Age (Year)}

Table 4.1 shows that more than $33.68 \%$ of the rural household heads who involved in non timber forest products extraction were within the age bracket of (41-50) years. This group represents those who are more economically involved in NTFPs extraction. This age bracket is followed by $28.42 \%$ in the range of (31-40) years. This implies that majority of them are in their active age and are very agile. The age range of (41-50) years had the highest percent $33.68 \%$ of those that involved in NTFPs extraction. This could be due to the fact that a lot of people would have taken it as an occupation while some would have joint them as a result of retirement or retrenchment.

\subsubsection{Gender}

Whereas both male and female were involved in NTFP extraction, the result of the study shows that most $61.05 \%$ of those involved in NTFPs extraction activities were males while the remaining $38.95 \%$ were females. This result shows 
that men are better positioned in terms of straight in extracting product from the forest. This finding supports the conclusion drawn in Usambara Tanzania, where Fleuret, (1979a) found that young people especially men commonly relied on the sales of wild leave for income generation.

\subsubsection{Educational Attachment}

Majority $71.58 \%$ of the respondents had one form of formal education or the other. The formal education they acquired is expected to aid them in their daily activities or programme. This level of education could influence their attitude toward marketing their products.

\subsubsection{Marital Status}

The study showed that more than $42.11 \%$ of rural household involved in extraction were married. This shows that people have the tendency to settle down to do their businesses. Married people also have the advantage of family labour than the unmarried. The reason for low percentage of widower could be that most men would have die due to old age. This result agrees with Subedi, (1999b) who stated that women poorer household participate in collection and sales of NTFPs.

\subsubsection{Occupation}

The study shows that more than $44.21 \%$ of respondents in the area were farmers and they also involved in NTFPs extraction while $8.42 \%$ of the respondents were solely involved in NTHPs extraction only.

\subsubsection{Household Size}

The result shows that most of the household sizes were in the range of $(6-10)$. This constitutes $49.47 \%$ of the respondents. This implied that majority of those who extract NTFPs have relative large house hold size.

\subsubsection{Forest Base Activities}

Table 4.2: Forest-Base Activities of the Respondents

\begin{tabular}{lcc}
\hline Variables Question & Frequency & Percentage\% \\
\hline Are you always allowed to collect (NTFPS) & 74 & 77.89 \\
YES & 21 & $22: 11$ \\
NO & 21 & $22: 11$ \\
Purpose of collecting the products & 35 & $36: 74$ \\
Income generation & 12 & $12: 63$ \\
Household use & 48 & $50: 53$ \\
Both & 44 & $46: 32$ \\
Do distance affect the quantities of you collect & 51 & $53: 68$ \\
Yes & & \\
No & 60 & $63: 16$ \\
Do you always get the products whenever you go for collection & 35 & $36: 84$ \\
Yes & & \\
No & 24 & $25: 26$ \\
& 71 & $74: 74$ \\
Does the market price of other products affect the market price of your products & & \\
Yes & & $17: 89$ \\
No & 17 & $34: 74$ \\
How are the various products sold & 33 & $47: 37$ \\
Singles & 45 & \\
Bundle & & \\
Both & & \\
\hline
\end{tabular}

Source: 2014 field data 
The studies revealed that majority $77.89 \%$ of the respondents are allowed to collect product from the forest while $22.11 \%$ are not allowed. This could be due to government policies and traditional law to reserve some area.

The table depicts the general purpose of collecting non timber forest products. The result implied that more than $50.53 \%$ of the respondents extract products for the purpose of income generation and household use. From the result of the study more than $46.36 \%$ of the respondents said that distance determine the quantity of products that is collected while $53.68 \%$ said that distance do not affect the quantity of products that is collected. The studies reveal that $36.84 \%$ of the respondents do not always get products. This could be due to bush burning, deforestation, and seasonal availability.

Table 4.2 shows that the price of other product does not affect their product due to the fact that most of the products from forest do not have closed substituted. The study showed that majority $70.51 \%$ faces, one difficulty or the other during the process of collection which could be as a result of scarcity deforestation, bush burning, et cetera. The result shows that majority $47.37 \%$ of the respondents sold their products singly or bundle.

\subsection{Challenges Encounter during Extraction of NTFPs}

Table 4.3 Challenges face by Rural Household who Extract Non Timber

Forest Products

\begin{tabular}{lcc}
\hline Challenges & Frequency & Percentage $\%$ \\
\hline Lack of marketing & 30 & 9.06 \\
Bush burning & 72 & 21.75 \\
Deforestation & 46 & 13.90 \\
Scarcity & 60 & 18.13 \\
Over exploitation & 55 & 16.62 \\
Distance from forest & 44 & 13.29 \\
Market price of other products & 24 & 7.25 \\
\hline
\end{tabular}

Source: 2011 field data.

The result presented in table 4.3 shows the general challenges that are face by various respondents. The study implied that more than $21.75 \%$ of respondents encounter the problem of bush burning. Follow by scarcity $18.13 \%$ which could be as a result of bush burning and seasonality in yield or weather. This is followed by over exploitation $16.62 \%$ then deforestation $13.90 \%$, then distance from the forest $13.29 \%$, and lack of market $9.06 \%$ finally market price for other products wa $7.25 \%$. If all the man made problems are check by the government, the welfares of forest dependent will improved.

\subsection{Regression Analysis of the Contribution of Non Timber Forest Products to Household Income}

The contribution of non timber forest products to rural household income was based on the assumption that the total income of rural household head is a function of size of household, income from non timber forest products, income of rural household head from other activities apart from non timber forest products, educational level with $\mathrm{O}$ for non formal education and 1 for formal education, gender of household with 1 gender is male and $\mathrm{O}$ if $\mathrm{g}$ ender is female and age in years. The essence was to investigate whether non timber forest product contributes significantly to rural household income.

\subsubsection{Hypotheses}

Ho: Extraction of non timber forest products does not have significant effect on the income of rural household. The linear function was chosen as the best fit because of the number of significant variables $R^{2}$ value conformity to a priori expectations and t-statistics.

The significance of the parameter of the model was evaluated by mean of linear regression at $1 \%$ level and $5 \%$ level of significance. 


\section{Table 4.4}

\begin{tabular}{|c|c|c|c|c|c|}
\hline Variable & & Coefficient & Std Error & T Statistics & Probe \\
\hline $\mathrm{C}$ & & 106326.55 & 45409.01 & 2.34 & 0.02 \\
\hline HHS & & -1317.99 & 3343.27 & -0.39 & 0.69 \\
\hline YNT & & 1.01 & 0.03 & 31.80 & 0.00 \\
\hline YEX & & 0.53 & 0.08 & 6.45 & 0.00 \\
\hline EDU & & -686.08 & 21679.68 & -0.03 & 0.97 \\
\hline GEN & & -7514.17 & 20750.17 & -0.36 & 0.72 \\
\hline AGE & & -704.92 & 870.08 & -0.81 & 0.42 \\
\hline Model & $\mathrm{R}$ & R square & Adjusted R square & \multicolumn{2}{|c|}{ St d Error of the estimate } \\
\hline 1 & .968 & .936 & .932 & \multicolumn{2}{|c|}{9339335838} \\
\hline
\end{tabular}

The estimated linear function presented below

$Y=-1317.99 x_{1}+1.01 x_{2}+0.53 x_{3}+-686.08 x_{4}+-7514.17 x_{5}+-704.92$

Keynes Theory

$\mathrm{R}$ square should be positive and equal to or less than 1.

$\mathrm{R}^{2}=0.94$ multiply by $100=94 \%$. It is significant at $1 \%$ and $5 \%$ level. In line with a priority expectation; non timer forest product contributes significantly to household income. The result from the analysis shows that income from non timber forest products $\left(\mathrm{x}_{2}\right)$ is statistically significant in affecting total income of rural household heads. This implied that non timber forest product is a major determinant factor of rural household head income.

Income from other activities apart from non timber forest products $\left(\mathrm{x}_{3}\right)$, similarly had a positive and significant relationship $(P<0.05)$ with income generate by rural household from other activities. This agrees with the earlier report of Akaeze, (2010) who stated that non timber forest products collection is correlated with income. The non timber forest product is significance at $5 \%$ level. This income complements that which is generated from non timber forest products. This result suggests that income generated only from the extraction of non timber forest products is not substantial to support the household expenditures. Household heads must therefore engage themselves in other economic activities to generate additional income.

\section{Conclusion}

It is true that rural household depends on non timber forest products for their survival. Indeed, forest can be tagged as our divine treasure. Forest related activities continue to form a major source of supplementary income to rural household. However; forest dependent are face with a lot of constraints as some of the products are going into extinction and the forest is gradually reducing. The non timber forest products contribute significantly to rural household income in

Knysna in the Eastern Cape of South Africa Area. Non timber forest products are very relevant in the rural cash economy.

\section{Recommendation}

Since (NTFPs) contributes to the income of rural household and subsequently improved their expenditures level in terms of clothing, chores, transport, education, medical care, purchases of farm implement, debt repayment, rent, et cetera. It is advisable therefore, that the forest should be maintained and sustained to enable the continuous collection of non timber forest products.

Based on the findings of the study, the following recommendations were made:

- There should be intensification of forest plantation programme which could result in the provision of enough forest products that will lead to increase in the per capital income of the household head.

- There should be public awareness/education campaign on forest issues as regard benefit derivable in terms of income generation and conservation of the forest for recreational purposes.

- Policies and strategies that aim at improving the welfare of rural people and natural resources conservation should give attention to the contribution of (NTFP) to the local people.

- Local arts preventing bush burning should be enacted through the Communities leadership.

- The rural people who depend on forest products should be carried along during forest policies formation. 
- Rural dwellers are increasingly depending on forest resources and agricultural products for their income. Since agriculture involved the felling of forest trees, policies and strategies should aim at increasing productivities and production of agricultural land per unit are through the use of improved technology and propagates for agriculture, so as to reduce disforestation.

\section{Acknowledgements}

We would like to thank God for His daily protection and His support. We would not have been able to complete this project without His support and guidance. Many thanks go to Prof. Adu for his assistance and guidance throughout the period to complete the paper. His support has been so immense and his suggestions played a crucial role in shaping the paper.

We would like to express our appreciation to all the respondents who have participated in the study for their time and valuable contribution without which it was almost impossible to see this paper to the completion point.

Lastly but by no means the least, we would like to thank the University of Fort Hare. This research would not be possible without their funding.

\section{References}

Abushe ,O. (2005), Effect of Fuelwood Exploitation on Income of Household (unpublished) Agric Project Work. Department of Agricultural Economics and Extension Delta State University Pp. 12, 52

Agbogidi, O.M. and A.U. Ofuoku (2006). Biodiversity conservation in Niger Delta Ata of Nigeria. Agricultural Conspectus Scientifics. 71 (3) $110-115$.

Akaeze, V.N. (2010), Forest Dependent survival (unpublished) Project Work. Agricultural Economic/Extension Delta State University. Pp 10,43

Andel, T.V. (2006), Non Timber Forest Products, the valve of wild plants. Agrobies India. Pp. 46 - 48.

Anon, P.A. (1996). World Resources. A Guide to the Global Environment Oxford University Press P. 365.

Barry, R.G and Chorley R.J. (1982), Atmospheric Weather and Climate. Metheien and Co. New York.

Blaikie, P. and Harold B. (1987), Land Degradation and the Society. London Mothuen New York.

Etukudo, I.G. (2000). Forest our Divine Treasure. Dorand Publisher p.o. Box 135 Uyo, Akwa Ibon State, Nigeria pp 6-7, 35.

FAO, (1990). The Relevance of Forestry to America Economic. Food and Agriculture Organization Rome.

FAO, (1997), State of the World's forest 1997, food and Agriculture Organization of the United nation Rome Italy.

FAO, (1999), Wood fuel flows Regional Wood Energy Development programme. Food and Agriculture Organization of United nation Rome

FAO, (2009), Forest Dependent Survival Strategies of Tribal Women: Implications for Joint Agriculture Organization. Rome Italy

FAO, (1990). The Relevance of Forestry to America Economic. Food and Agriculture Organization Rome.

FAO, (2008). Wood fuel flows Regional Wood Energy Development programme. Food and Agriculture Organization of United nation Rome

Flueret, O.A. (1979a). The Contributions of Non Timber Forest Products Resources to Rural Household income. In Usambara Tanzania. The Rural Energy Crisis, poverty and Women's Role in Tanzania

Frank, H.W. (1997). Forest Production for Tropical Americal (USDA) United States Department of Agriculture.

Gale, I.A. (2001). Forestry Work in Austria. Gale Encyclopaedia of Science Thomson Gale 2001 [On-line]. Available: en.wikipedia. org/wiki/forestry. [Accessed: July 22, 2014].

(IITA) International Institute of Tropical Agriculture, (1986). Trees and Schrubs key to Increased food production. In the Tropic Oyo Road Ibadon Nigeria.

Laarman, Y. and Rodger, S. (1992). Global Forest Issue for Six Billion People. Ngraw-Hill Inc, New York p 337-338.

Lietz, E., Hans B.P., Peter, H and Alexander, M. (1999). Agriculture and the Environment (Perspective on Sustainable Rural Development Edward Smart Australia pp. 105.

Lynch, O.J. and Talbott, K. (1992). Balancing Act Community base Forest Management and National Law Asia and the pacific World Resource Institute. Washington.

NEST Nigeria Environmental Study/Action Team, (2003). Climate Change In Nigeria: A communication Guide for reporters and Education pp 27 - 35.

Soper, R., Taylor, D.J., G neen, N. P.O. and Stact, G.W. (1997). Biological Science pp. 666-669.

Subedi, (1999b). Socio-Economic and Institutional impacts of community based ecosystem management project in Humla, Nepal. Kathinandu, Nepal, Asia Network for Small-Scale Bio researches (ANSAB)

Tukudo, I.G., Attah, U.I, Udofia, A. and Akpauebe, I.N. (1994). Element of Forestry Uyo. Usanoa and Sow Enterprise

WCFSD World Commission on Forest and Substinable Development. Geneud, (1997). Our Future, Our Forests Final Report on the World. 